\title{
Thermal structure and drainage system of a small valley glacier (Tellbreen, Svalbard), investigated by ground penetrating radar
}

\author{
K. Bælum ${ }^{1}$ and D. I. Benn ${ }^{1,2}$ \\ ${ }^{1}$ Department of Geology, University Centre in Svalbard (UNIS), Longyearbyen, Norway \\ ${ }^{2}$ School of Geography and Geosciences, University of St Andrews, UK
}

Received: 13 October 2010 - Published in The Cryosphere Discuss.: 21 October 2010

Revised: 17 February 2011 - Accepted: 18 February 2011 - Published: 4 March 2011

\begin{abstract}
Proglacial icings accumulate in front of many High Arctic glaciers during the winter months, as water escapes from englacial or subglacial storage. Such icings have been interpreted as evidence for warm-based subglacial conditions, but several are now known to occur in front of coldbased glaciers. In this study, we investigate the drainage system of Tellbreen, a $3.5 \mathrm{~km}$ long glacier in central Spitsbergen, where a large proglacial icing develops each winter, to determine the location and geometry of storage elements. Digital elevation models (DEMs) of the glacier surface and bed were constructed using maps, differential GPS and ground penetrating radar (GPR). Rates of surface lowering indicate that the glacier has a long-term mass balance of $-0.6 \pm 0.2 \mathrm{~m} /$ year. Englacial and subglacial drainage channels were mapped using GPR, showing that Tellbreen has a diverse drainage system that is capable of storing, transporting and releasing water year round. In the upper part of the glacier, drainage is mainly via supraglacial channels. These transition downglacier into shallow englacial "cut and closure" channels, formed by the incision and roof closure of supraglacial channels. Below thin ice near the terminus, these channels reach the bed and contain stored water throughout the winter months. Even though no signs of temperate ice were detected and the bed is below pressuremelting point, Tellbreen has a surface-fed, channelized subglacial drainage system, which allows significant storage and delayed discharge.
\end{abstract}

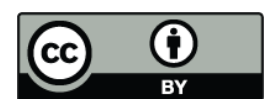

Correspondence to: $\mathrm{K}$. Bælum (karolineb@unis.no)

\section{Introduction}

Large icings (also known as naled ice) accumulate each winter in front of many glaciers in Svalbard. Although snowmelt can occur during brief periods of positive air temperature in winter (Humlum et al., 2003), this source of water is insufficient to explain either the volume or quasi-continuous accumulation of proglacial icings, and the out-flowing water most likely indicates the release of water from en- or subglacial storage. Traditionally the presence of large icings has been interpreted as evidence for warm-based polythermal conditions (Hagen et al., 2003a), under which water can be produced subglacially throughout the year. Some studies have shown that icings also occur in front of glaciers that are predominantly or entirely cold-based (Hodgkins, 1997), although in such cases the location and distribution of stored water are not well understood.

There have been comparatively few investigations of drainage systems on predominantly cold based arctic glaciers with evident outflow of water in the winter season (Hodgkins, 1997; Temminghoff, 2009; Van Hoof, 2008), and considerable uncertainty exists about the source, flowpath, and residence time of such water. In this study, we use GPR data to investigate the thermal characteristics, structure, and drainage system of Tellbreen, a small valley glacier in central Spitsbergen. Specifically, the aims of this paper are: (1) to determine the thermal regime of the glacier, particularly whether there are any areas of temperate ice, (2) to establish the location of stored water within and beneath the glacier, and its relationship with englacial and subglacial drainage channels, and (3) to determine changes in the area, volume and thickness of the glacier since the Little Ice Age, to provide a context for other data. 


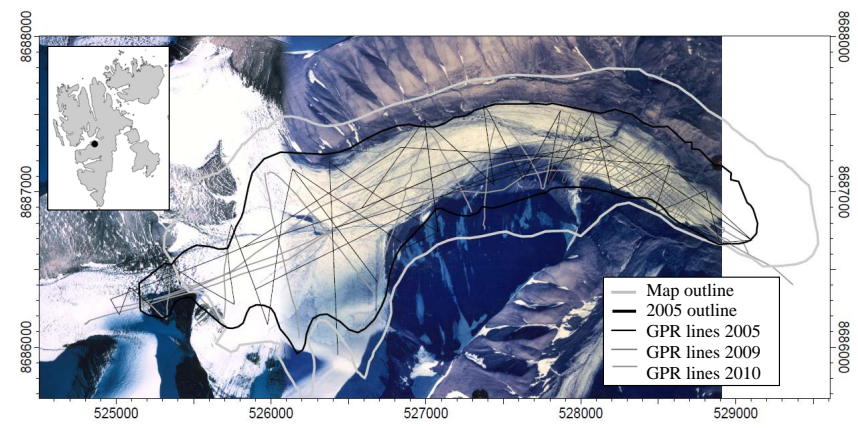

Fig. 1. Location of Tellbreen (inset) and 1995 aerial photo with map outlines, ca. 1938 (thick grey), 2005 outline (thick black) and GPR lines from 2004-05 (dark grey), 2009 (grey) and 2010 (lower third of the glacier, light grey).

\section{Setting}

The Archipelago of Svalbard consists of all islands located between $74^{\circ}$ and $80^{\circ} \mathrm{N}$ and $10^{\circ}$ and $35^{\circ} \mathrm{E}$. The climate is relatively mild and dry compared to other locations at similar latitudes, with an average annual air temperature of $-6{ }^{\circ} \mathrm{C}$ and a mean annual precipitation of $400 \mathrm{~mm}$ in the central part of Spitsbergen, the main island (Engeset and Ødegård, 1999). Sixty percent of the land area is covered by glaciers (Hagen et al., 1993).

Tellbreen is a $3.5 \mathrm{~km}$ long, land terminating valley glacier situated at $78.13^{\circ} \mathrm{N}, 16.5^{\circ} \mathrm{E}$ in the centre of Spitsbergen (Fig. 1), $20 \mathrm{~km}$ northeast of the main settlement, Longyearbyen. It has not previously been the objective of scientific investigations and the only data available for the glacier are the GPR and GPS measurements described in this paper, a handful of snow pits and the maps and aerial photographs described in Sect. 3.2. The glacier's basic properties (estimated from aerial photos from 1977) are listed in the Glacier Atlas of Svalbard and Jan Mayen (Hagen et al., 1993) (Table 1). The median elevation is $580 \mathrm{~m}$.a.s.l. which is very close to the mid point of the glacier $(570$ m.a.s.l) indicating a simple hypsometry with an area to height ratio of close to one. Hagen et al. (1993) estimated the volume of the glacier from the ice covered area (A) observed on the 1977 aerial photos and the mean depth (D) which is estimated by

$\mathrm{D}=33 \times \ln \mathrm{A}+25$

Tellbreen has a well defined catchment area, a single firn area and has experienced substantial retreat of the terminus since the end of the Little Ice Age (LIA). The elevation of the equilibrium line is not known but it is evident that the accumulation area is very limited as the glacier is close to snow-free on the 1995 aerial photograph from mid August. A substantial percentage of the accumulation is believed to be in the form of superimposed ice and avalanches from the steep mountainsides surrounding the glacier. A large icing and areas of open water occur every winter in front of the glacier termi- nus. We have observed open water in front of the glacier even at times when temperatures were below $-20^{\circ} \mathrm{C}$, indicating release of stored englacial or subglacial water.

The geology of the area consists of sub-horizontal, poorly cemented and readily erodible fluvial and shallow marine sand- and siltstones of Cretaceous to Eocene age (Hjelle, 1993). There are no known faults directly under Tellbreen, but the major Billefjorden fault zone is found $10 \mathrm{~km}$ to the east. Furthermore there are several faults in nearby De Geerdalen and under Archowskifjellet (Dallmann et al., 1999). The significance of the geological setting will be discussed later.

Traditionally, it has been assumed that drainage on cold arctic glaciers is entirely supraglacial, because melt water is unable to penetrate cold ice (Hodgkins, 1997). However, recent work has shown that two mechanisms can enable surface melt water to reach the interior, and sometimes the bed, of predominantly cold polythermal glaciers (Gulley et al., 2009b). Firstly, incision of perennial surface meltwater channels can form meandering englacial passages if their upper, abandoned levels become blocked by snow or ice, or closed by ice creep (Gulley et al., 2009a). Such "cut-and-closure" conduits commonly form in lateral positions due to the convex shape of the ablation area (e.g. Longyearbreen: (Gulley et al., 2009a; Hansen, 2001; Humlum et al., 2005), although they can also occur close to the glacier centreline (e.g. Austre Brøggerbreen: (Vatne, 2001). Cut-and-closure conduits can incise down to glacier beds and form subglacial channels in cold ice (e.g. (Gulley et al., 2009a; Humlum et al., 2005 ), although channels below depths of $\sim 20 \mathrm{~m}$ of ice are very susceptible to blockage, and water tends to be re-routed to shallower flow paths.

The second mechanism for routing surface meltwater through cold ice is overdeepening of water-filled crevasses, or hydrofracturing (Alley et al., 2005; Benn et al., 2009; Boon and Sharp, 2003; van der Veen, 2007). Hydrofracturing can occur where ice under tensile deviatoric stress coincides with a sufficient water supply. This process allows surface-to-bed drainages (moulins) to develop on a seasonal basis, and can enable the water to access deep, warm areas of glacier beds through great thicknesses of cold ice. On Tellbreen, the ice surface is mostly smooth with no major crevasse areas. Although some isolated extensional crevasses occur on the upper part of the north-west side of the glacier, and bergschrunds occur near its upper limit, we have found no evidence for surface-to-bed drainage by hydrofracturing on Tellbreen. Surface melt water follows well-defined supraglacial channels in the upper part of the glacier, with a shift to an arborescent system of partly englacial, 10-20 m deep, incised lateral channels in the lower part. 
Table 1. Volume and areas from 3-D models and calculated by Eq. (1). The values are plotted in Fig. 4.

\begin{tabular}{llccccc}
\hline Year & & $\begin{array}{c}\text { Area in } \\
\mathrm{km}^{2}\end{array}$ & $\begin{array}{c}\text { Calculated from Hagen 1993 } \\
\text { Mean ice } \\
\text { thickness in } \mathrm{m}\end{array}$ & $\begin{array}{c}\text { Volume in } \\
\mathrm{km}^{3}\end{array}$ & $\begin{array}{c}\text { 3-D model } \\
\text { Mean ice } \\
\text { thickness in m }\end{array}$ & $\begin{array}{c}\text { Volume in } \\
\mathrm{km}^{3}\end{array}$ \\
\hline $1910^{\mathrm{a}}$ & LIA maximum & 6.4 & 86 & 0.55 & 90 & 0.48 \\
$1938^{\mathrm{b}}$ & Map vis. ice & 5.8 & 83 & 0.48 & 72 & 0.42 \\
1977 & Glacier atlas & 5.4 & 81 & 0.44 & - & - \\
1995 & vis. ice & 3.0 & 61 & 0.18 & - & - \\
1995 & $\mathrm{~d}_{\text {ice }}=0^{\mathrm{d}}$ & 4.0 & 71 & 0.28 & - & - \\
2005 & vis. ice $^{\mathrm{e}}$ & 2.6 & 57 & 0.15 & 50 & 0.13 \\
2005 & $\mathrm{~d}_{\text {ice }}=0$ & 3.0 & 61 & 0.18 & 50 & 0.15 \\
2009 & vis. ice $^{\mathrm{e}}$ & 2.5 & 55 & 0.14 & 52 & 0.13 \\
2009 & $\mathrm{~d}_{\text {ice }}=0$ & 2.8 & 59 & 0.17 & 50 & 0.14 \\
\hline
\end{tabular}

a Estimated from the height and distribution of LIA moraines above the 1995 surface.

b Modelled in Petrel from NP 1:100.000 series map (based on aerial photos from 1936-38).

${ }^{c}$ Extent of glacier ice on aerial photographs.

$\mathrm{d}$ The limits of the ice inferred from the radar lines.

e Ice with no detectable debris cover in radar lines. Average ice thickness $\mathrm{d}_{\text {ice }}=33 \ln \mathrm{A}+25$. Volume $V=\mathrm{A} \times \mathrm{d}($ Hagen et al., 1993$)$.

\section{Methods}

\subsection{GPR}

During the spring field seasons of 2004, 2005 and 2009 a total of $98 \mathrm{~km}$ of GPR lines were recorded on Tellbreen with about $50 \%$ being repetitive to detect changes in the glacier geometry. In 2010, a total of $26 \mathrm{~km}$ were recorded in a grid covering the lower third of the glacier (Fig. 1). The equipment used in 2004-2005 was a PulseEKKO 100 radar triggered by an odometer wheel. The antennae were mounted on a wooden sledge perpendicular to the direction of movement with equidistant spacing of one antenna length between them. This was done to minimize line interferences from objects either side of the lines and to optimize the amount of energy transmitted directly into the ground (Annan and Cosway, 1992) as the antenna radiation pattern is that of a half wavelength dipole (Daniels, 1996). A snow scooter was used to tow the sledge and carry the rest of the equipment. We used 50 and $100 \mathrm{MHz}$ resistively damped dipolar antennae, with bandwidths equal to their centre frequency (Daniels, 1996).

In 2009 and 2010, a Målå radar system with fixed, unshielded $100 \mathrm{MHz}$ antennae was used. The antennae were inline with an equidistant spacing of two antenna lengths between them. Since the antennae array is fixed in a Kevlar tube, this system does not allow for making a common mid point (CMP) survey. Petterson et al. (2003) state the theoretical values for clean dry ice as $0.168 \pm 0.003 \mathrm{~m} / \mathrm{ns}$. Since Tellbreen is assumed to be cold throughout a value of $0.17 \mathrm{~m} / \mathrm{ns}$ was used for depth conversion of the GPR data from Tellbreen.

For all the GPR lines a Garmin Etrex legend GPS was used for positioning. Kinematic Differential GPS (DGPS) measurements covering most of the glacier surface were collected in April 2009. These measurements were used to model the 2009 surface. The accuracy given by the GPS was in most cases $5-10 \mathrm{~m}$ in the horizontal plane. Points with lesser accuracy were not used. The vertical accuracy was $3-8 \mathrm{~m}$ in 2009 when comparing the GPS to the DGPS measurements taken at the same location. A vertical error of $10 \mathrm{~m}$ corresponds to $2-3 \%$ of the total heights in m.a.s.l. The topographic maps of the area have contour interval of $50 \mathrm{~m}$, so this error is negligible with respect to the topographic models presented.

\subsection{Aerial photographs and maps}

To provide context for interpretation of the radar data, long term geometric changes of Tellbreen were reconstructed using four 3-D models of the glacier surface, based on aerial photographs, map and GPS data. The most recent aerial photographs of Tellbreen are the Norwegian Polar Institute 1:15000 series from 1990 and 1995. For this investigation the pictures used were the S95 series picture 1226 and 1227 and the S90 series pictures 4611, 4612, 5175 and 5176. From these the outline and position of surface features could be mapped in UTM coordinates. The new edition of the Norwegian Polar Institute (NPI) 1:100.000 map series of the area was produced from this series, whereas the previous edition was based on the 1936-38 series. Unless otherwise stated, the map outlines refer to the 1936-38 series map whereas the 1995 outline is taken from the 1995 aerial photographs. All coordinates on the maps produced in this paper, except Fig. 1, are in UTM ED50.

The volumes and ice thicknesses were calculated in two ways; from the relationship between area and average ice thickness stated by Hagen et al. (1993) (Eq. 1) and from the 
3-D models described in Sect. 3. For the 2005 and 2009 models an estimate of both the area of ice visible on aerial photos (interpreted as ice with no discernable debris cover in the radar data) and the total ice covered area (where ice thickness was zero) was modelled. The LIA maximum extent of the glacier was approximated by raising the NPI (1936-39) map surface to the maximum level of the prominent ice-cored moraines that flank the glacier.

\subsection{Processing}

The raw GPR data were processed in ReflexW (2004 and 2005) and Rad Explorer (2009 and 2010). The processing mainly consisted of applying gain and filters (Background and DC removal, spherical divergence correction and AGC (Automatic gain control)). The 2010 lines used for amplitude mapping were not subjected to any gain function in order not to bias the amplitude information.

In the 2004-2005 data the bottom reflector was picked and the two-way travel time (TWT), depth, amplitude and phase were exported into Petrel. In 2009 and 2010, the lines were depth-converted using a velocity of $0.17 \mathrm{~m} / \mathrm{ns}$ and converted into the standard SEG-Y format before being imported directly into Petrel. A digital elevation model (DEM) of the area was created by digitizing the NPI 1:100.000 map. The ice thickness maps and DEMs are not a direct representation of the individual lines but rather an overall smoothed picture of the glacier. Not all of the glacier was accessible by snow scooter and ca. $3 \mathrm{~km}^{2}$ are covered by the GPR lines. The models for 2005-2009 have a grid size of $30 \times 30 \mathrm{~m}$ which is much larger than the step size $(0.5-1.5 \mathrm{~m})$ and 10 times the theoretical coverage as the data points are not evenly distributed on the glacier surface. A grid of $20 \times 20 \mathrm{~m}$ was used for the areas covered by the 2010 data. A comparison between the radar lines from 2005 and 2009 and the two models created from the lines did not show significant differences. When comparing the GPR data to the DEM models it was clear that due to the smoothing effect of the modelling there is a local slight underestimation of the greatest ice thicknesses by $3-5 \mathrm{~m}$. This will also influence the bottom topography maps and the average depth and volume estimates but to a very limited degree. The accuracy of the models based on maps and aerial photos are difficult to quantify since no GPR data exist from before 2004.

The models were made with a minimum of smoothing while still obtaining reasonable ice thickness contour lines. The bottom reflector can be picked within $\pm 5 \mathrm{~ns}$ corresponding to $0.4 \mathrm{~m}$. A potentially more significant error is the computation of the depth from the TWT. The velocity of pure, cold ice is $0.172 \pm 0.005 \mathrm{~m} / \mathrm{ns}$ (Bogorodsky et al., 1985). This amounts to an error of $42.5 \mathrm{~ns}$ or $5.8 \mathrm{~m}$ of ice assuming an ice thickness of $100 \mathrm{~m}$.

The underestimation of the ice thickness due to the omission of the effect of surface snow is very limited and is therefore not taken into account. The velocity in dry firn is

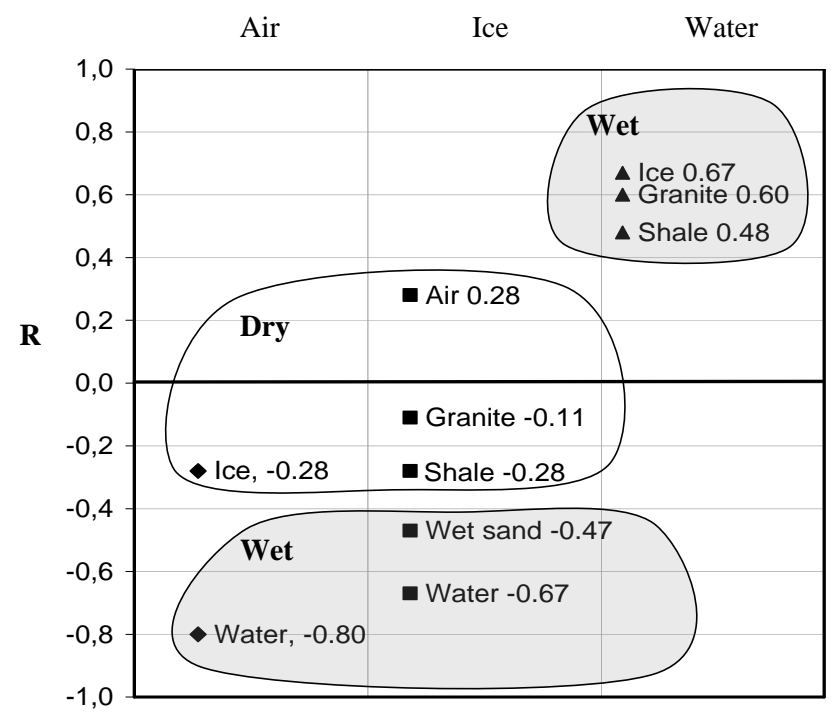

Fig. 2. Examples of reflection coefficients $(R)$ for various interfaces found in a glacial environment. The top caption is the material above the interface; the data labels state the material below the interface and the reflection coefficient. It is clear that the presence of water is connected to a strong reflection. Values from Davis and Annan (1989) and Murray et al. (1997).

$0.19 \mathrm{~m} / \mathrm{ns}$ (Pettersson et al., 2003; Bogorodsky et al., 1985) and $0.22 \mathrm{~m} / \mathrm{ns}$ for hard packed snow. This translates to a time difference in TWT of $5 \mathrm{~ns}$ if a $2 \mathrm{~m}$ snow layer replaces ice, equivalent to $0.4 \mathrm{~m}$ of ice.

The magnitude and polarity of a reflector can give indications of the nature of the interface. Analysis of the polarity and strength of the bottom reflector is a widely used approach to determine areas of water at the interface (e.g. (Gades et al., 2000; Copland and Sharp, 2001; Pattyn et al., 2009). The reflection coefficient $(R)$ is a measure of the amount of energy reflected at an interface. Assuming that the conductivity is negligible $(\sigma \approx 0)$ it follows that the magnetic permittivity $\mu \approx \mu_{0}$ when operating at very high frequencies $(1 \mathrm{MHz}-$ $2 \mathrm{GHz})$. The relative dielectric permeability of a material $\left(\varepsilon_{r}\right)$ is the permittivity of the material $\varepsilon$ in relation to the permittivity in free space $\varepsilon_{0}$. The reflection coefficient for a planar surface can then be expressed as:

$R=\left(\sqrt{\varepsilon_{r, 1}}-\sqrt{\varepsilon_{r, 2}}\right) /\left(\sqrt{\varepsilon_{r, 1}}+\sqrt{\varepsilon_{r, 2}}\right)$

Where the index number 1 refers to the material above the interface and 2 the material below (Reppert et al., 2000). A negative reflection coefficient relates to a shift in polarity of the wave. The reflection coefficients for the most common interfaces found in a glacial environment can generally be divided into two major groups: dry and wet (Fig. 2). Dry interfaces (e.g. ice to shale, air to ice) have reflection coefficients between -0.3 and +0.3 indicating that less than $30 \%$ of the incoming wave is reflected back towards the receiving antenna. Wet interfaces (e.g. air to water, ice to wet sand) 
reflect as much as $80 \%$ of the incoming wave and are most often associated with a shift in polarity. An exception to this rule are interfaces where water is the top layer, but as the field work was done in winter this type of interface will be intra- or subglacial and therefore overlain by an interface with $R<0$.

In order to map the properties of the glacier bed the relative magnitude, scaled down to $[-1 ; 1]$, and the polarity of the wave at the ice-bed reflection, were extracted from the data. This was done using the Surface Attribute function in Petrel. The algorithm used was a sum of amplitudes function. For each trace the amplitude was calculated for a $5 \mathrm{~ns}$ window centred on the bed reflector (the estimated accuracy to which the reflector could be picked). The attenuation of radar waves in cold ice is low, in most cases below $30 \mathrm{~dB} / \mathrm{km}$ (Bentley et al., 1998; MacGregor et al., 2007; Winebrenner et al., 2003). The ice thickness in the area covered by the 2010 radar lines (Fig. 1) is less than $40 \mathrm{~m}$ (in $80 \%$ of the area it is less than $25 \mathrm{~m}$ ). The attenuation is small compared to the strength of the signal and has not been incorporated in the calculation of the bed echo. Future work on Tellbreen, e.g. collecting data for and producing a detailed bed reflection map of the whole glacier, could include a more detailed analysis of the attenuation pattern.

From these values a contour map of the relative bed reflection amplitude was produced using a minimum curvature algorithm with low grade smoothing (Fig. 3). This gives an indication of the areas where there are strong indications of a wet interface. When combining (i) the maps of ice thickness and (ii) the locations where structures consistent with a subglacial channel are observed in the radar line, this method presents a useful tool to resolve the origin and transport of the water feeding the icing in front of the glacier.

\section{Results and interpretations}

\subsection{Temporal changes in geometry, area and volume}

The long-term geometric changes of Tellbreen from the last 100 years are presented in Table 1 and Figs. 4, 5 and 6. At the LIA maximum (approximately 90 years ago; (Hagen et al., 2003a; Hodgkins, 1997; Navarro et al., 2005)), the glacier had a volume of $0.47 \mathrm{~km}^{3}$, compared with $0.42 \mathrm{~km}^{3}$ in $1936-38$, and less than $0.2 \mathrm{~km}^{3}$ in 2009 . Thus, in a period of less than 100 years since the end of the LIA Tellbreen has lost some $60-70 \%$ of its total volume and the glaciated area has been reduced by more than $50 \%$. The long-term mass balance of the glacier (in metres water equivalent per year) was calculated using the measured surface lowering and an average of the glaciated area, and was found to be $-0.6 \pm 0.2 \mathrm{~m} / \mathrm{yr}$. This figure is close to the $-0.55 \mathrm{~m} / \mathrm{yr}$ (Dowdeswell et al., 1997) for Svalbard glaciers as a whole, and glaciers of comparable size and geometry, such as Austre Brøggerbreen $\left(5 \mathrm{~km}^{2},-0.45 \pm 0.33 \mathrm{~m} / \mathrm{yr}\right)$, Bertilbreen $\left(5 \mathrm{~km}^{2}, \quad-0.72 \pm 0.29 \mathrm{~m} / \mathrm{yr}\right)$, Longyearbreen

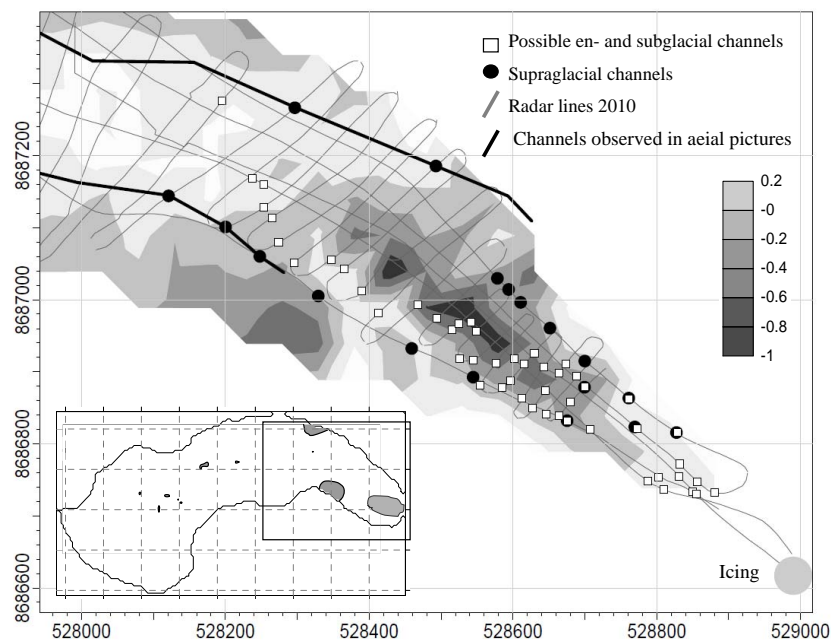

Fig. 3. Relative amplitude of the ice-bed reflector near the terminus of Tellbreen (2010). The dark grey areas have values below -0.5 , significantly lower than would be expected from a dry interface, and are most likely linked to the presence of water at the ice-rock/sediment interface. The insert of the whole glacier with map outline is from the 2009 survey but the areas with anomalies are coinciding.

$\left(4 \mathrm{~km}^{2},-0.55 \pm 0.45 \mathrm{~m} / \mathrm{yr}\right)$ and Aldegondabreen $\left(7.6 \mathrm{~km}^{2}\right.$, $-0.7 \mathrm{~m} / \mathrm{yr}$ ) (Hagen et al., 2003b; Navarro et al., 2005).

\subsection{Drainage channels}

Numerous isolated englacial reflectors (Fig. 7) were observed in the radar data. In the unmigrated data, the structures consist of strong hyperbolae located in otherwise transparent ice or just above the bed. These display a reversal of polarity and a reflection pattern consistent with models of air- and partially water-filled englacial channels (Stuart et al., 2003; Vatne, 2001). An englacial channel with a circular or oval cross section will present as a single symmetric hyperbola, whereas a canyon-like morphology (typical of many cut-and-closure type conduits) appears as a series of slightly offset, stacked hyperbolae (cf. Van Hoof, 2009). More complex reflection patterns can be expected for channels close to the bed, or within debris-rich ice. The polarity and amplitude of the reflected wave is dependent on the reflection coefficients at the interface (Fig. 2).

An example of a structure interpreted to be an englacial channel is shown in Fig. 7b. The first arrival from the channel is the reflected R-wave (white-black-white) from the top of the channel. The next arrival is the reversed polarity (blackwhite-black) TRT-wave that is transmitted $(T)$ through the ice- air interface at the top of the channel, reflected from the air water interface $(R)$ and transmitted $(T)$ through the air-ice interface. As the reflection coefficient is -0.80 this results in a high amplitude, reversed polarity signal. The TRRRTwave is a peg-leg from within the air filled part of the cavity. 


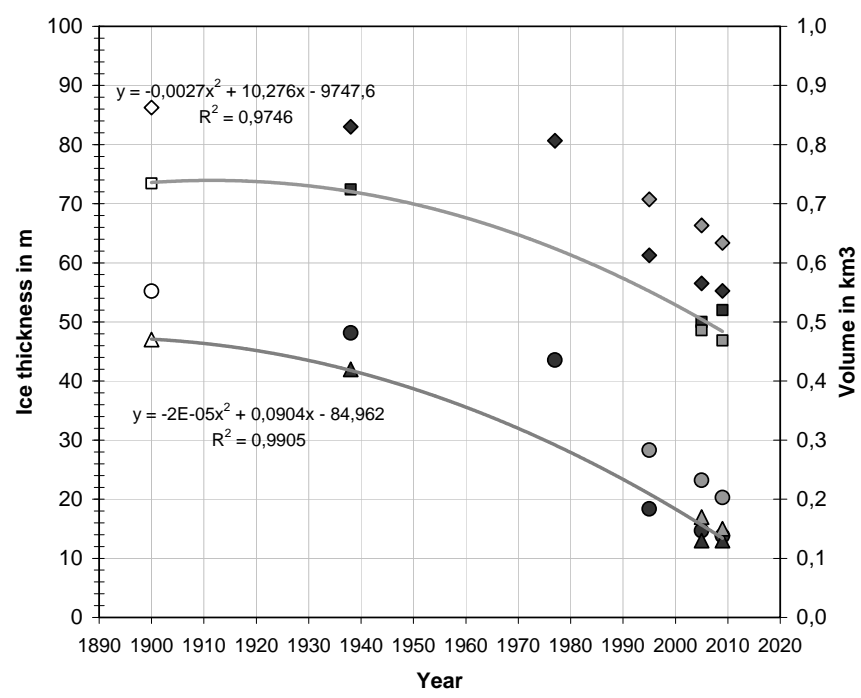

Calculated ice thickness, visible ice area

Calculated ice thickness, $Z=0$

area

Calculated LIA ice thickness maximum area

- Ice thickness from model, visible

口 Ice thickness from model, $\mathrm{Z}=0$

$\checkmark \quad$ Ice thickness from model, LIA maximum area

- Calculated volume, visible area

○ Calculated volume, $Z=0$ area

O Calculated volume, LIA

maximum area

- Volume from model, visible ice

area

$\Delta$ Volume from model, $\mathrm{Z}=0$ area

$\Delta$ Volume from model, LIA maximum area

Fig. 4. Plot of mean ice thickness (upper curve) and volumes (lower curve) of Tellbreen as a function of time. The calculated volumes are derived from Eq. (1). The values can be found in Table 1.

The TTRTT wave originates from the bottom of the channel (the water-ice interface). The TTRRRTT-wave is again an echo, this time from a peg-leg within the water. Because the propagation velocities of electromagnetic waves in ice, water and air are well established (Annan and Cosway, 1992), the dimensions of the channel can be estimated. Assuming the channel has a close to circular cross section, the height is ca. $2.3 \mathrm{~m}$, with a water level around $1.5 \mathrm{~m}$. For air-filled channels, the reflection pattern will consequently be simpler. The TRT wave originates from the bottom of the air-ice interface at the bottom of the channel and the amplitude is comparatively smaller $(R=-0.28)$. The TRRRT-wave can still be observed but not the TTRRRTT-return.

For a snow-covered supraglacial channel (Fig. 7a) the general pattern will be the same but the overlying ice will in this case be replaced by a snow bridge with a higher velocity. Assuming a simple U-shaped cross section and a uniform snowbridge the depth of the channel can be estimated to ca. $2 \mathrm{~m}$.

A subglacial channel can be challenging to detect if no water is present, due to the low reflection coefficient of ice overlying dry materials. The reflection pattern of a circular, partly or completely water filled subglacial channel is similar to those of an englacial channel (Fig. 7c). However, the reflection from the bed of the channel (TRT or TTRTT depending on the water level) will originate from a water-rock/moraine interface with a lower reflection coefficient than a water-ice interface. Subglacial channels show a large variance in size, shape and geometry, often resulting in a complicated reflection pattern complicating the estimation of geometry and water content.
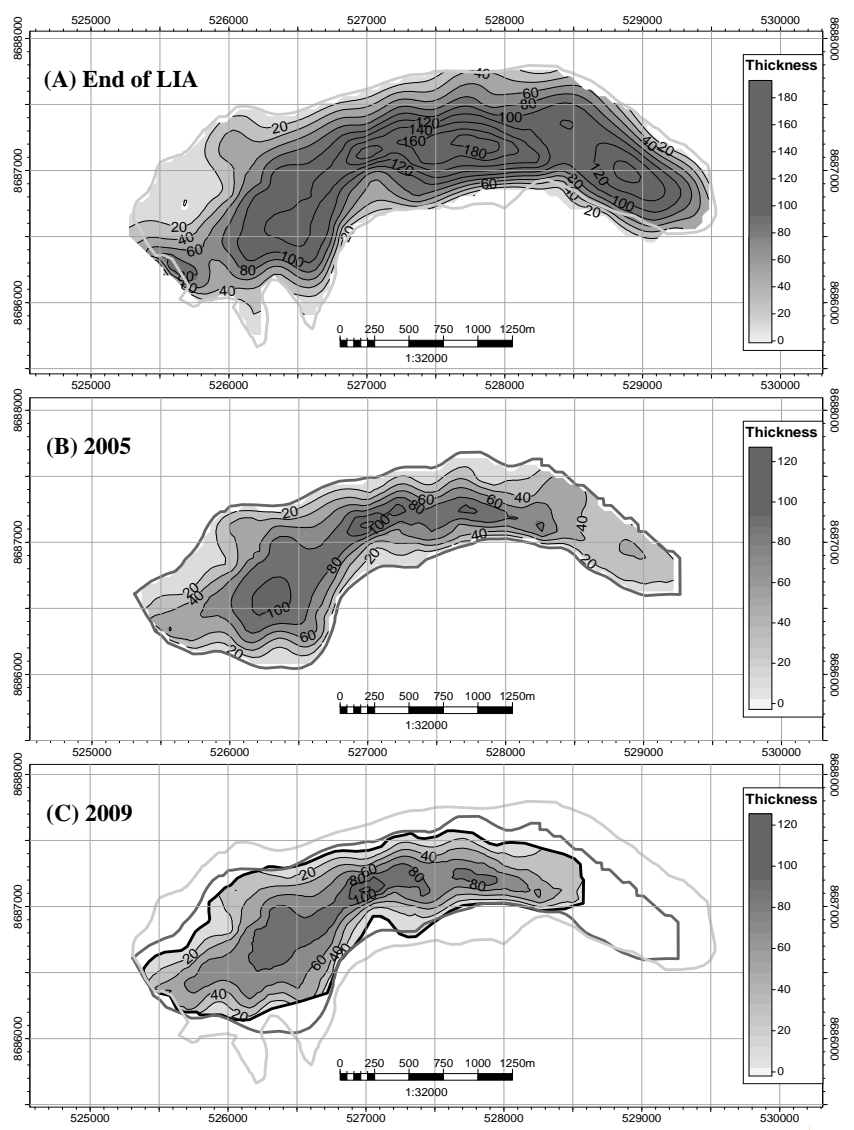

Fig. 5. Ice thickness maps and outlines of the glaciated area. NP 1:100.000 series map (light grey), 2005 measurements (dark grey) and 2009 measurements (black). 

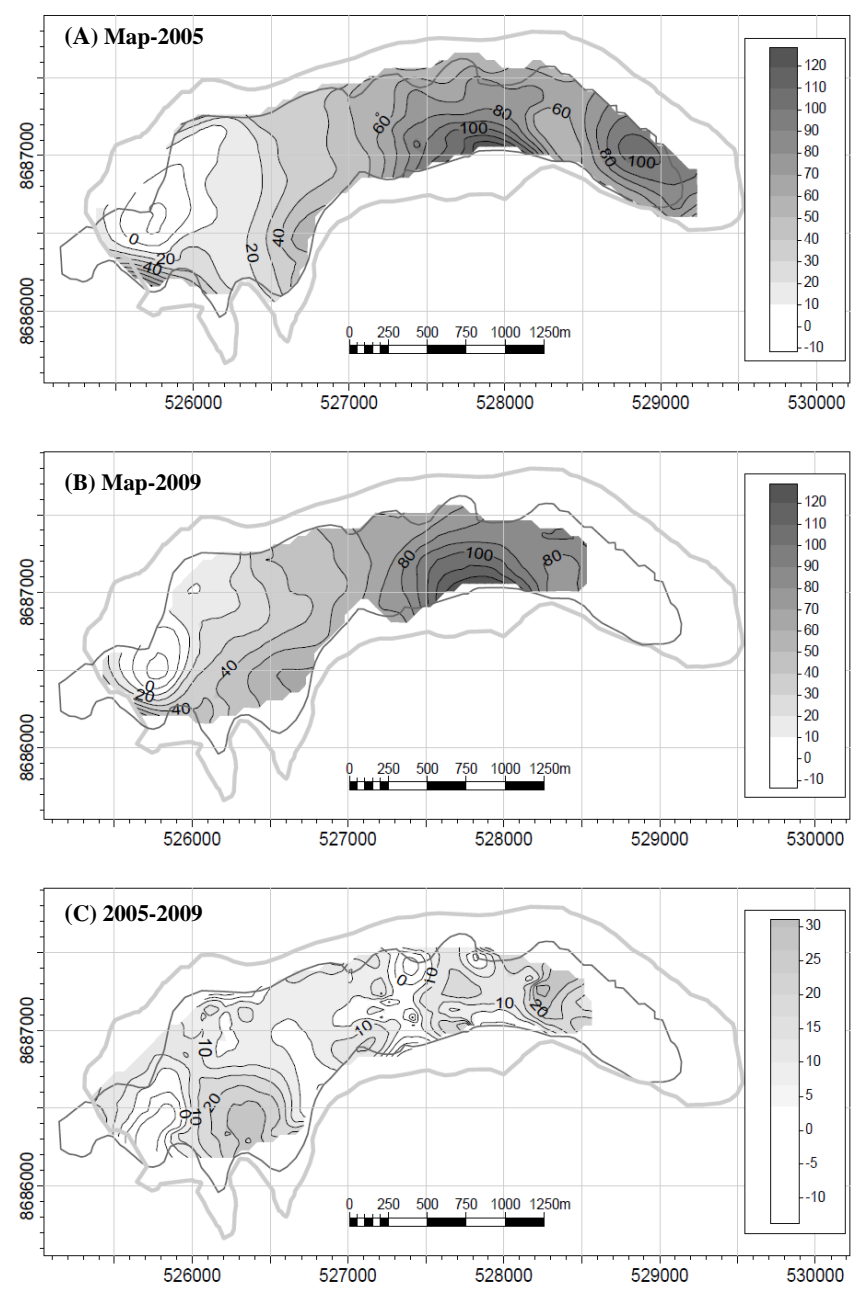

Fig. 6. The change in surface elevation and outline of Tellbreen. Norwegian Polar Institute A7 map, 1:100.000 series outline (light grey) and 2005 area covered by GPS measurements (dark grey).

\subsection{Basal conditions}

A composite of the reflection strength from the 2004, 2005 and 2009 lines shows two areas with high bed reflection power and a distinctly negative reflection coefficient (insert on Fig. 3, dark grey areas). One of these areas is near the thickest part of the glacier, and is limited in extent. It is likely that this marks a small, isolated region of wet-based ice as there are no indications of temperate ice in the radar lines crossing this area. The second area occurs beneath the glacier terminus, where the ice is typically less than $20 \mathrm{~m}$ thick. The terminus area was investigated in detail in 2010 (Fig. 3), and the areas with the strongest reflectors and most prominent shift in polarity are highly localized and coincide with structures at or near the bed consistent with a water-bearing channels. There are no indications of widespread wet basal conditions beneath the terminus. Except for the areas described above in the inset on Fig. 3 there is no evidence for water
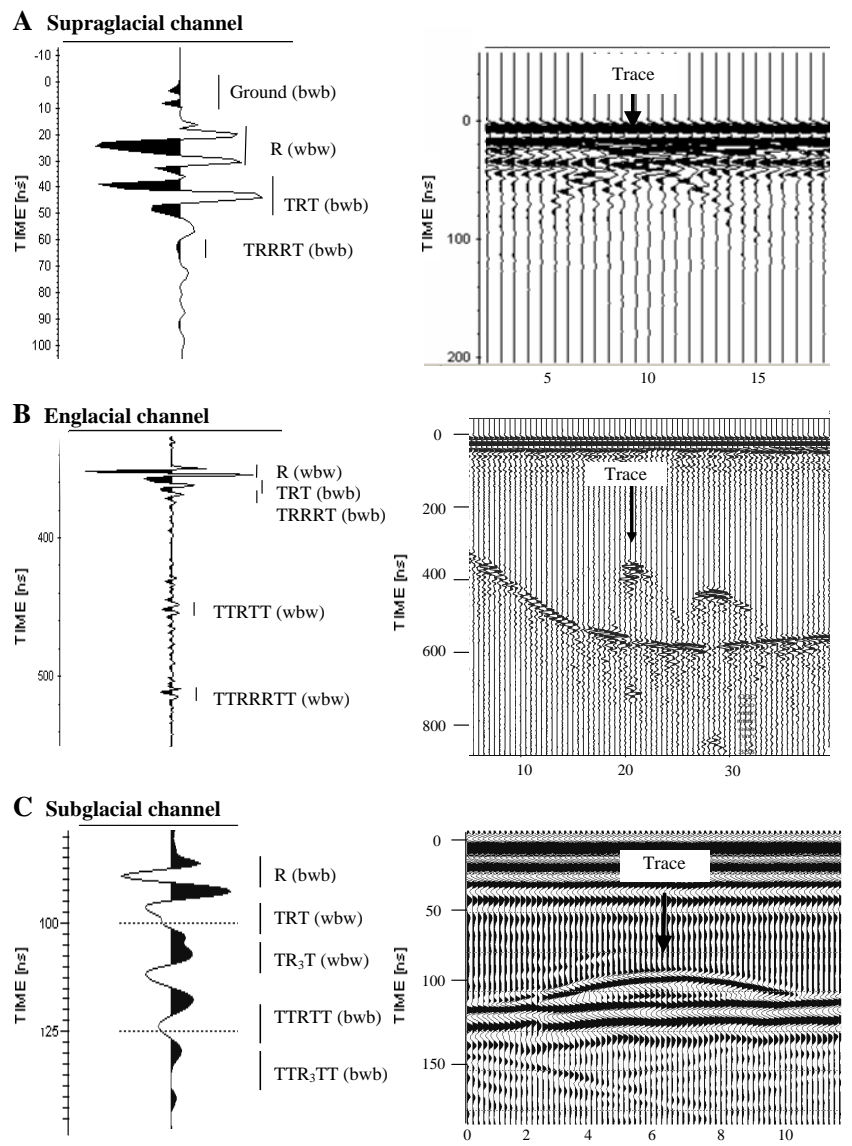

Fig. 7. Wavelet traces and GPR profiles from drainage channels. Vertical scale is in ns TWT, horizontal in $\mathrm{m}$. (A) ca. $2 \mathrm{~m}$ deep, lateral melt water channel. The curvature of the hyperbola indicates a velocity of around $0.22 \mathrm{~m} / \mathrm{ns}$, a reasonable value for a snow filled channel. (B) Englacial channel. Detail from a cross glacier line. The radar signature can be interpreted as a $2 / 3$ water filled englacial channel ca. $2.3 \mathrm{~m}$ in diameter. (C) Partially water filled subglacial channel near the terminus. A and $\mathbf{B}$ are from the 2009 data set, $\mathbf{C}$ is from 2010.

at the bed at distances greater than $1 \mathrm{~km}$ from the terminus, where the ice is more than $30 \mathrm{~m}$ thick. However, englacial reflectors, consistent with partially water-filled englacial channels (Fig. 7b), are found further up on the glacier. Figure 8 is a cross section through the glacier tongue with all channels marked on Fig. 3 plotted as a function of depth and distance to the profile (over or under $50 \mathrm{~m}$ ). At distances of 600 $700 \mathrm{~m}$ from the terminus, the channels are mostly englacial but approaching subglacial. Along the centreline closer to the terminus the majority of the channels are near or at the bed while they are mainly supraglacial near the margins and the terminus where the ice thickness is less than $15 \mathrm{~m}$. This drainage pattern is not consistent with the traditional view of the evolution of drainage systems of cold-based glaciers but it is congruent with recent findings on the distribution and characteristics of cut-and-closure conduits (e.g. Gulley et al., 2009b; Van Hoof, 2009). 


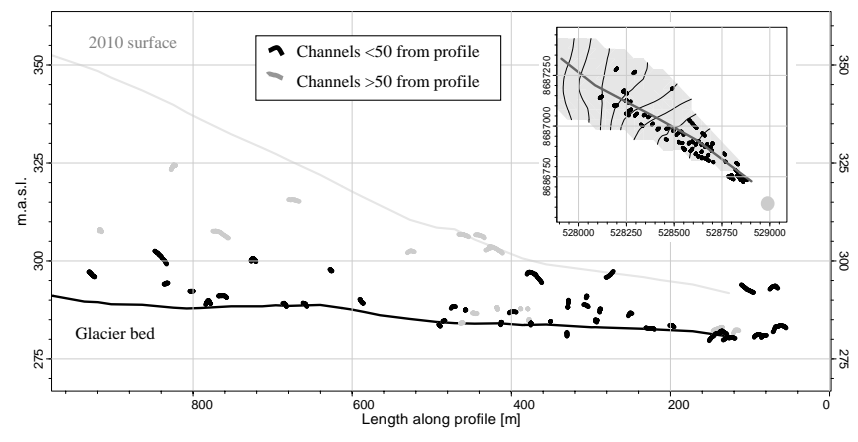

Fig. 8. Cross section of terminus with all channels identified in the 2010 lines plotted in map view (small inset) and as a function of depth and length along the profile. The channels are coloured according to distance from profile line. As the surface and bed of the glaciers changes laterally some of the channels are located above the surface and below the bed of the profile.

\section{Discussion}

\subsection{Thermal regime}

The bed reflector below Tellbreen is generally very clear and distinct, and the overlying ice transparent with few structures. In warm-based polythermal glaciers, there is typically a well defined transition zone from cold ice to warm ice (Irvine-Fynn et al., 2006; Sund and Eiken, 2004; Pälli, 2003; King et al., 2008), due to the change in water content. In GPR data, this is indicated by a shift from a clear layer with few reflections to a more opaque and noisy layer with numerous small reflections. This effect due to the backscattering of the GPR waves by small scale water bodies within the temperate ice. As no water is present in the cold ice this appears transparent. Several of these interfaces have been confirmed by boreholes (Hodgkins et al., 1997; Jacobel et al., 2002; Pettersson et al., 2003; Ødegård and Hagen, 1997). No such change in radar signature was observed anywhere on Tellbreen. There is no evidence in the radar data of a temperate surface layer in the upper part of the glacier, such as has been observed on other Svalbard glaciers (Type A polythermal regime; Blatter and Hutter, 1991). This is in line with the very limited accumulation area and the absence of firn in all snow pits dug on the glacier. On several Svalbard glaciers, cold-temperate transition surfaces (CTS) have been reported at depths approaching or equal to the ice thickness of Tellbreen (Melvold et al., 2003; Riger-Kusk, 2006; Sund and Eiken, 2004; Ødegård and Hagen, 1997). However, except for the small, isolated area near the thickest part of the glacier (Fig. 3), there is no evidence for warm-based ice below Tellbreen. Based on the data available, Tellbreen appears to be almost entirely cold.

In a few areas in the upper part of the glacier, complex reflectors occur in the basal zone, interpreted as a $5-15 \mathrm{~m}$ thick layer of debris-rich ice. These areas are not coincident

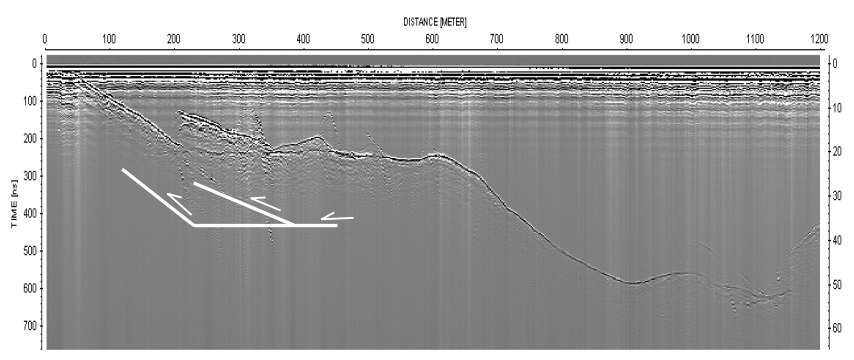

Fig. 9. A thrust fault near the terminus of the glacier. Detail from line running from the terminus up the centre of the glacier. Top and right hand scales are in $\mathrm{m}$, left hand is TWT in ns. Notice the $600 \mathrm{~m}$ of ice that is less than $30 \mathrm{~m}$ thick. Gain and dewow are applied. Also noticeable is the completely transparent ice with no evidence of backscattering.

with the areas of a wet interface indicated in Fig. 3. There were also several examples of narrow, inclined structures in the lower part of the glacier which rise downglacier at angles of 5 to $15^{\circ}$. These are interpreted as thrust faults (Fig. 9). The possible presence of both debris-rich ice and thrust faults suggests that the glacier may have been partly warm-based at its LIA maximum when parts of the glacier could have been as much as $200 \mathrm{~m}$ thick (Fig. 5). Greater ice thicknesses and, possibly, greater ice fluxes would have encouraged warming of basal ice by geothermal and strain heating. At that time the glacier would have had a significant accumulation area and could have been a Type A or Type $\mathrm{C}$ polythermal glacier in the Blatter and Hutter (1991) classification. However, despite the underlying geology being readily erodible (see Sect. 2) the DEMs of the valley beneath the glacier show a distinct V-shape and low degree of modification, as would be expected below a cold based glacier (Etzelmüller et al., 2000). This suggests that, although parts of Tellbreen may have experienced warm-based conditions at times, they were neither widespread nor prolonged.

There are no indications that Tellbreen has experienced the retreat-advance cycles or subsequent shape changes that are linked to a surge type glacier. The glacier is not currently building up mass in the upper part or undergoing significant increases of surface gradient (Fig. 6). Also there are no indications that the glacier terminus has advanced further into the valley than the LIA extent marked on Figs. 5 and 6. The undisturbed and patterned ground in front of the glacier shows no signs of having been glaciated in the last several thousand years, which is the timescale of formation of largescale patterned ground and ice wedge formation (Mackay, 1990). Taken together with the absence of historical records of the glacier surging, it is concluded that Tellbreen is not of surge type. 


\subsection{Water in the glacier}

Below the glacier terminus, subglacial water appears to be restricted to discrete channels, and there is no evidence for a widespread water film at the bed. In this context, it is relevant that other areas of thin ice around the margins of the glacier are apparently everywhere frozen to the bed (Fig. 9), as is typically the case for Svalbard glaciers. The inferred basal channels do not have any apparent subglacial catchment areas. Instead, it appears likely that they are fed by englacial channels located farther up glacier, which in turn are fed at their upper ends by supraglacial channels. The drainage system of the glacier, therefore, appears to reflect currently active processes (incision and roof closure of supraglacial channels), and has not been inherited from a different thermal regime, as has been suggested for englacial channels elsewhere in Svalbard (e.g. Stuart et al., 2003). Cut-and closure conduits appear to be very widespread on uncrevassed parts of Svalbard glaciers (Gulley et al., 2009a, b), and have been observed in subglacial positions below thin ice near glacier termini. For example, cut-and-closure channels existed at the bed of the cold-based Longyearbreen between 2001 and 2003 (Humlum et al., 2005), although this channel subsequently became blocked and water was re-routed at a higher level within the glacier (Gulley et al., 2009a). Other examples have been observed near the termini of Scott Turnerbreen (Temminghoff, 2009) and Rieperbreen (Gulley, unpublished data). Cut-and-closure channels develop where channel incision rates exceed ice surface ablation rates, a process which will tend to bring them into contact with the glacier bed. Channel blockage, however, becomes more likely at greater depths where ice-creep closure rates are higher. This reduces the likelihood that such channels can persist below ice thicker than a few tens of metres. In contrast, cut-and-closure channels could persist below the thin ice near glacier termini, where water could be stored during the winter months.

The results of this study have wider implications for understanding the hydrology of High Arctic glaciers. Firstly, water flow from beneath glaciers during winter cannot be used to infer warm-based conditions, because subglacial storage does not imply subglacial water production. Secondly, the drainage systems of cold Arctic glaciers can be considerably more complex than envisaged in traditional conceptions of glacial hydrology. According to the widely-used model of Shreve (1972), englacial water flow is guided by potential gradients within the ice, and can only occur under temperate conditions. It is now widely recognized that hydrofracturing can allow surface water to penetrate cold ice (e.g. Alley et al., 2005; Krawczynski et al., 2009), but it is now clear that the cut-and-closure mechanism is also capable of creating integrated supraglacial-englacial-subglacial drainage networks in entirely cold glaciers. Finally, the routing of oxygenrich surface waters to cold glacier beds implies that such drainage systems can accomplish localized subglacial chemical weathering. Cold high Arctic glaciers, therefore, are not necessarily passive components of the landscape, but can exhibit complex linkages with the atmosphere and lithosphere.

\section{Conclusions}

Since the end of the LIA, Tellbreen has lost $\sim 60-70 \%$ of its volume and the glaciated area has been reduced by more than 50\%. The long-term mass balance of the glacier (in metres water equivalent per year) was calculated to be $-0.6 \pm 0.2 \mathrm{~m} \mathrm{yr}-1$. The GPR data indicate that Tellbreen is currently entirely cold-based, with the possible exception of a small, isolated region near the thickest part of the glacier. It is possible that the glacier had areas of warm ice during the LIA maximum, although the low degree of modification and 3-D models of the underlying valley suggests that the glacier has never had high erosional potential. There is no evidence of surge behaviour.

Despite cold-based conditions, water exits beneath part of the glacier all year round, and in the winter months feeds a large icing in front of the glacier. Our results indicate that water is stored during the winter months in two or more narrow channels beneath the lowermost $400-500 \mathrm{~m}$ of the glacier tongue, from where it is gradually released. These channels are apparently the downglacier continuations of englacial channels, which in turn are fed by supraglacial channels higher up the glacier. When seen in connection with the outflow of water from the glacier in winter and the absence of ice at the pressure melting point in the upper part of the glacier, this presents a strong argument for the hypothesis that, despite being an entirely cold arctic glacier, Tellbreen, contrary to the traditional view of cold based glaciers, has a diverse, subglacial drainage system that is capable of storing, transporting and releasing water year round. Results also indicate that Tellbreen has been cold based for a significant amount of time. The present drainage system of Tellbreen is therefore possibly not a relic from a previous polythermal regime but has developed in response to processes currently active on the glacier.

Acknowledgements. Fieldwork was funded by a Norwegian Polar Institute Arctic Field Grand and UNIS. We thank M. Riger-Kusk, R. Behlke, Q. Nuna, H. Rasmussen, L. J. Baddeley , C. Eide, M. Waage and U. Silver for their indispensable help during fieldwork.

Edited by: I. M. Howat 


\section{References}

Alley, R. B., Dupont, T. K., Parizek, B. R., and Anandakrishnan, S.: Access of surface meltwater to beds of sub-freezing glaciers: preliminary insights, Ann. Glaciol., 40, 8-14, 2005.

Annan, A. P. and Cosway, S. W.: Ground penetrating radar survey design, Paper prepared for the annual meeting of SAGEEP, Chicago, Sensors \& Software, 1992.

Benn, D. I., Gulley, J., Luckman, A., Adamek, A., and Glowacki, P.: Englacial drainage systems formed by hydrologically driven crevasse propagation, J. Glaciol., 55(191), 513-523, 2009.

Bentley, C. R., Lord, N., and Liu, C.: Radar reflections reveal a wet bed beneath stagnant ice stream. $\mathrm{C}$ and a frozen bed beneath ridge bc, west antarctica, J. Glaciol., 44, 149-156, 1998.

Blatter, H. and Hutter, K.: Polythermal conditions in Arctic glaciers, J. Glaciol., 37(126) 261-269, 1991.

Bogorodsky, V. V., Bentley, G. R., and Gudmandsen, P. E.: Radioglaciology, Dordrecht, etc., D. Reidel Publishing Co., 1985.

Boon, S. and Sharp, M.: The role of hydrologically-driven ice fracture in drainage system evolution on an Arctic glacier, Geophys. Res. Lett., 30(18), 1916-1920, 2003.

Copland, L. and Sharp, M.: Mapping thermal and hydrological conditions beneath a polythermal glacier with radio-echo sounding, J. Glaciol., 47(157), 232-242, 2001

Dallmann, W. K., Andresen, A., Bergh, S. G., Harmond Jr, D. M., and Ohta, Y.: Tertiary fold-and-thrust belt of Spitsbergen Svalbard, Norsk Polarinstitut, Oslo, Meddelelser, 128, 1-46, 1993.

Daniels, D. J.: Surface-penetrating radar, Electron. Commun. Eng., August, 165-182, 1996.

Davis, J. L. and Annan, A. P.: Ground-penetrating Radar for high-resolution mapping of soil and rock stratigraphy, Geophys. Prospect., 37, 531-551, 1989.

Dowdeswell, J. A., Hagen, J. O., Björnsson, H., Glazovsky, A. F., Harrison, W. D., Holmlund, P., Jania, J., Koerner, R. M., Lefauconnier, B., Simon, C., Ommanney, L., and Thomas, R. H.: The mass balance of circum-Arctic glaciers and recent climate change, Quaternary Res., 48, 1-14, 1997.

Engeset, R. V. and Ødegård, R. S.: Comparison of annual changes in winter ERS1 SAR images and glacier mass balance of Slakbreen, Svalbard, Int. J. Remote Sens., 20(1), 259-271, 1999.

Etzelmüller, B., Ødegård, R. S., Vatne, G., Mysterud, R. S., Tonning, T., and Sollid, J. L.: Glacier characteristics and sediment transfer system of Longyearbreen and Larsbreen, western Spitsbergen, Norsk Geogr. Tidsskr., 54(4), 157-168, 2000.

Gades, A. M., Raymond, C. F., Conway, H., and Jacobel, R. W.: Bed properties of Siple Dome and adjacent ice streams, West Antarctica, inferred from radio-echo sounding measurements, J. Glaciol., 46(152), 88-94, 2000.

Gulley, J. D., Benn, D. I., Müller D., and Luckman, A.: A cut-andclosure origin for englacial conduits in uncrevassed regions of polythermal glaciers, J. Glaciol., 55(189), 66-80, 2009a.

Gulley, J., Benn, D. I., Screaton, L., and Martin, J.: Englacial conduit formation and implications for subglacial recharge, Quaternary Sci. Rev., 28(19-20), 1984-1999, 2009b.

Hagen, J. O., Kohler, J., Melvold, K., and Winther, J.-G.: Glaciers in Svalbard: mass balance, runoff and freshwater flux, Polar Res., 22(1), 145-159, 2003a.

Hagen, J. O., Melvold, K., Pinglot, F., and Dowdeswell, J.: On the net mass balance of the glaciers and ice caps in Svalbard, Norwegian Arctic, Arct. Antarct Alp. Res., 35(1), 264-270, 2003 b.
Hagen, J. O., Liestøl, O., Roland, E., and Jørgensen, T.: Glacier atlas of Svalbard, Norsk Polarinstitut, Oslo, Norway, 1993.

Hansen, O. H.: Internal drainage of some subpolar glaciers on Svalbard, Master thesis, University of Bergen, 2001.

Hjelle, A.: Svalbards Geologi, Norsk Polarinstitut, Oslo, Norway, 1993.

Hodgkins, R.: Glacier hydrology in Svalbard, Norwegian High Arctic, Quaternary Sci. Rev., 16, 957-973, 1997.

Hodgkins, R., Tranter, M., and Dowdeswell, J. A.: Solute provenance, transport and denudation in a high arctic glacierized catchment, Hydrol. Process., 11, 1813-1832, 1997.

Humlum, O., Elberling, B., Hormes, A., Fjordheim, K., Hansen, O. H., and Heinemeier, J.: Late-Holocene glacier growth in Svalbard, documented by subglacial relict vegetation and living soil microbes, Holocene, 15(3), 396-407, 2005.

Humlum, O., Instanes, A., and Sollid, J. L.: Permafrost in Svalbard: a review of research history, climatic background and engineering challenges, Polar Res., 22(1), 191-215, 2003.

Irvine-Fynn, T. D. L., Moorman, B. J., Williams, J. L. M., and Walter, F. S. A.: Seasonal changes in ground-penetrating radar signature observed at a polythermal glacier, Bylot Island, Canada, Earth Surf. Proc. Land. 31, 892-909, 2006.

Jacobel, R. W., Peterson, E. M., Stone, D. R., and Fountain, A. G.: Studies of englacial water in Storglaciären using GPR-year two, Tarfala Research Station, annual report 2001-2002, 3-8, 2002.

King, E. C., Smith, A. M., Murray, T., and Stuart, G. W.: Glacierbed characteristics of midtre Lovénbreen, Svalbard, from highresolution seismic and radar surveying, J. Glaciol., 54, 145-156, 2008.

Krawczynski, M. J., Behn, M. D., Das, S. B., and Joughin, I.: Constraints on the lake volume required for hydro-fracture through ice sheets, Geophys. Res. Lett., 36, L10501, 2009.

MacGregor, J. A., Winebrenner, D. P., Conway, H., Matsuoka, K., Mayewski, P. A., and Clow, G. D.: Modeling englacial radar attenuation at siple dome, west antarctica, using ice chemistry and temperature data, J. Geophys. Res., 112, F03008, 2007.

Mackay, J. R.: Some observations on the growth and deformation of epigenetic, syngenetic and anti-syngenetic ice wedges, Permafrost Periglac., 1, 15-29, 1990.

Melvold, K., Schuler, T., and Lappegard, G.: Ground-water intrusions in a mine beneath Höganesbreen, Svalbard: assessing the possibility of evacuating water subglacially, Ann. Glaciol., 37, 269-274, 2003.

Murray, T., Gooch, D. L., and Stuart, G. W.: Structures within the surge front at Bakaninbreen, Svalbard, using ground-penetrating radar, Ann. Glaciol., 24, 122-129, 1997.

Navarro, F. J., Glazovsky, A. F., Macheret, Yu. Ya., Vasilenko, E. V., Corcuera, M. I., and Cuadrado, M. L.: Ice-volume changes (1936-1990) and structure of Aldegondabreen, Spitsbergen, Ann. Glaciol., 42, 158-162, 2005.

Ødegård, R. S. and Hagen, J. O.: Comparison of radio-echo sounding $(30 \mathrm{MHz}-1000 \mathrm{MHz})$ and high resolution borehole temperature measurements at Finsterwalderbreen, southern Spitsbergen, Ann. Glaciol., 24, 262-268, 1997.

Pälli, A.: Polythermal Glacier studies in Svalbard determined by groundpenetrating radar, PhD Thesis, Department of Geosciences, University of Oulu, Oulu, Finland, 2003.

Pattyn, F., Delcourt, C., Samyn, D., de Smedt, B., and Nolan, M.: Bed properties and hydrological conditions underneath McCall 
Glacier, Alaska, USA, Ann. Glaciol., 50, 80-84, 2009.

Pettersson, R., Jansson, P., and Holmlund, P.: Cold surface layer thinning on Storglaciären, Sweden, observed by repeated ground penetrating radar surveys, J. Geophys. Res., 108(F1), 60046005, 2003.

Reppert, P. M., Morgan, F. D., and Toksöz, M. N.: Dielectric constant determination using ground-penetrating radar reflection coefficients, J. Appl. Geophys., 43, 189-197, 2000.

Riger-Kusk, M.: Hydro-chemical and GPS investigations of Longyearbreen, a cold based glacier on Svalbard, Master Thesis, Aarhus University, Denmark and University Courses of Svalbard, Norway, 2006.

Shreve, R. L.: Movement of water in glaciers, J. Glaciol., 11, 205214, 1972.

Stuart, G., Murray, Y., Gamble, N., Hayes, K., and Hodson, A.: Characterization of englacial channels by ground-penetrating radar: An example from Brøggerbreen, Svalbard, J. Geophys. Res., 108(B11), 2525-2538, 2003.

Sund, M. and Eiken, T.: Quiescent-phase dynamics and surge history of a polythermal glacier: Hessbreen, Svalbard, J. Glaciol., 50(171), 547-555, 2004.
Temminghoff, M.: Characterization of the englacial drainage system in Scott Turnerbreen, Svalbard, by speleological mapping and ground-penetrating radar, Master thesis, University Courses of Svalbard, Norway, 2009.

Van der Veen, C. J.: Fracture propagation as means of rapidly transferring surface meltwater to the base of glaciers, Geophys. Res. Lett., 34(1), L01501-6, 2007.

Van Hoof, K.: Characterization of englacial conduits in Longyearbreen, Svalbard, by speleological mapping and groundpenetrating radar, Master thesis, University Courses of Svalbard, 2008.

Vatne, G.: Geometry of englacial water conduits, Austre Brøggerbreen, Svalbard, Norsk Geogr. Tidsskr., 55, 85-93, 2001.

Winebrenner, D. P., Smith, B. E., Catania, G. A., Conway, H. B., and Raymond, C. F.: Radio-frequency attenuation beneath siple dome, west antarctica, from wide-angle and profiling radar observations, Ann. Glaciol., 37, 226-232, 2003. 